\title{
Sosialisasi Penerapan Sistem Aquaponik Sederhana Terhadap Budidaya Tanaman Kangkung di Desa Pasiran, Kabupaten Asahan
}

\author{
Nurul Jannah ${ }^{1}$, Melinia Maduratna ${ }^{2}$, Ade Widya Claudia ${ }^{3}$ \\ 1,2,3 (Program Studi Pendidikan Biologi, Universitas Islam Negeri Sumatera Utara, Indonesia).
}

* Corresponding Author. E-mail: 1 nj427293@gmail.com

Receive: $13 / 05 / 2021$

Accepted: 23/08/2021

Published: 01/10/2021

\begin{abstract}
Abstrak
Aquaponik menjadi salah satu kunci dalam membuka peluang usaha ditengah pandemic covid-19 yang menjajah disetiap sudut kehidupan. Penerapan system aquaponk sederhana tentu akan membantu perekonomian dan wawasan masyarakat khususnya di Desa Pasiran, Kec. Sei Dadap, Kab, Asahan yang memiliki sebagian besar bekerja sebagai petani untuk memenuhi asupan sehari-hari. Penelitian ini bertujuan untuk mengetahui pertumbuhan tanaman kangkung dengan system aquaponik sederhana dengan memanfaatkan limbah anorganik sebagai media penanaman bibit kangkung. Penelitian ini menggunakan Penelitian Kualitatif dengan riset focus group discussion (FGD) peyampaian secara langsung kepada masyarakat di Desa Pasiran sebagai stakeholders penerapan system aquaponik dilingkungan rumah. Penelitian ini melakukan sosialisasi kepada masyarakat dengan mengadakan pertemuan di Balai Desa Pasiran, memberikan penyuluhan dan kegiatan tanya jawab terkait konsep system aquaponik sederhana. Hasil penelitian menunjukkan pertumbuhan pada kangkung terjadi dengan baik dan cepat berkembang. Dan dengan adanya system aquaponik sederhana, masyarakat dapat mengkonsumsi sayuran organic bebas dari bahan kimia serta menjadi peluang usaha ditengah pandemic virus covid-19.
\end{abstract}

Kata Kunci: Aquaponik, Limbah Anorganik, Masyarakat Pasiran, Produksi

\begin{abstract}
Aquaponics is one of the keys in opening business opportunities in the midst of the covid-19 pandemic that colonizes every corner of life. The application of a simple aquaponk system will certainly help the economy and community insight, especially in Pasiran Village, Kec. Sei Dadap, Kab, Asahan who has mostly worked as farmers to meet daily intake. This research aims to find out the growth of kale plants with a simple aquaponics system by utilizing inorganic waste as a medium of planting kale seedlings. This research uses Qualitative Research with focus group discussion (FGD) research directly to the community in Pasiran Village as stakeholders in the application of aquaponics system in the home environment. This research conducts socialization to the community by holding meetings at Pasiran Village Hall, providing counseling and question and answer activities related to the concept of a simple aquaponics system. The results showed that growth in kale occurs well and quickly develops. And with a simple aquaponics system, people can consume organic vegetables free of chemicals and become a business opportunity in the midst of the covid-19 virus pandemic.
\end{abstract}


Jurnal Edumaspul, 5 (2), Year 2021 - 57

(Nurul Jannah, Melinia Maduratna, Ade Widya Claudia)

Keywords: Aquaponics, Inorganic Waste, Pasiran Society, Production

\section{Pendahuluan}

Pandemic virus covid-19 pertama kali muncul di Wuhan salah satu kota di China. Saat ini banyak sekali sector kehidupan yang harus menanggung akibat dari adanya wabah tersebut. Hal ini sangat berdampak pada perekonomian keluarga menjadi sulit dan membutuhkan income lain untuk membantu kelangsungan hidup (Dewi Kania Widyawati, dkk, 2021:2). Sistem aquaponik merupakan salah satu sistem terintegrasi antara akuakultur dengan hidroponik.

Dimana limbah budidaya ikan berupa sisa metabolisme dan sisa pakan dijadikan pupuk untuk tanaman. Tanaman yang sering digunakan dalam aquaponik adalah sayuran. Tanaman aquaponik sangat cocok digunakan jika memiliki kemampuan dalam nutrisi yang larut dalam air. Disamping itu, tanaman aquaponik juga memiliki manfaat besar antara lain seperti serat, vitamin, dan mineral yang cukup baik bagi kesehatan (Dian Puspitasari, dkk, 2020:68). Prinsip dasar aquaponik adalah dapat dilakukan pada waktu yang bersamaan dengan cara pemanfaatan limbah kotoran ikan dan sisa makanan ikan sebagai sumber nutrisi bagi tanaman yang dibudidayakan (Laela Endah Rahmadhani, dkk, 2020:33).

Terdapat tiga jenis komponen pada sistem aquaponik yaitu tanaman, ikan, dan bakteri yang menguntungkan. Sistem aquaponik berkelanjutan umumnya dirancang untuk menyediakan lingkungan buatan yang optimal dalam pertumbuhan dan perkembangan pada ikan dan sayuran dengan menghemat sumber daya air. Pemanfaatan lahan sempit dengan pengaplikasian system aquaponik dapat menghasilkan suatu usaha dan panga berupa ikan dan sayuran (Dewi Kania Widyawati, dkk, 2021:2-3).

Kebutuhan lahan diluar pertanian terus mengalami peningkatan di kawasan perkotaan. Minimnya lahan yang tersedia mendorong masyarakat perkotaan untuk mencoba memenuhi kebutuhan pangan yang sehat dan berkelanjutan (Ni Wayan Sri Suliartini, dkk, 2021:107).

Umunya jenis tanaman yang dipakai dengan system aquaponik seperti kangkung, pakcoy, sawi, dan selada. (Ni Wayan Sri Suliartini, dkk, 2021:110). Tanaman kangkung salah satu jenis sayuran yang banyak dikonsumsi oleh penduduk Indonesia. Umunya budidaya kangkung lebih banyak diproduksi dengan tehnik budidaya lahan pertanian yang luas. Ketersedian air menjadi salah satu pengaruh proses pertumbuhan dan perkembangan pada tanaman kangkunng. Nutrisi pada tanaman kangkung diperoleh dari penyerapan oleh akar-akar tanaman kangkung terhadap nutrisi yang ada. Pada Sistem Aquaponik, tanaman menyerap nitrat yang ada pada perairan. Senyawa nitrat dihasilkan dari proses nitrifikasi yang dimanfaatkan sebagai sumber nutrisi oleh tanaman kangkung. Setelah proses tersebut maka air yang telah diserap limbahnya oleh tanaman air pada sistem aquaponik dapat kembali dialirkan pada kolom budidaya sehingga tidak memberikan pengaruh yang buruk berupa penurunan kualitas air dan konsentrasi amonia menurun (Lukito Hasta Pratopo, dkk, 2021:69).

Lingkungan adalah tempat kita hidup, semua makhluk hidup senantiasa bergantung pada alam dan lingkungan sekitar (Ervina Mukharomah, dkk, 2021:33). Isu yang sering beredar mengenai permasalahan lingkungan merupakan suatu topik yang sudah sering didengar yaitu masalah sampah mulai sari tingkatan lokal, regional, nasional dan internasional. Karena itu, kita sebagai makhluk bumi harus senantiasa menjaga keseimbangan dan kelestarian lingkungan disekitar kita (Dita Agustian, 2017:43). Sampah sebagai salah satu konsekuensi dari adanya kegiatan manusia. Sampah plastic menjadi salah satu jenis yang keberadaanya mendominasi di lingkungan rumah. Mulai dari kerusakan lingkungan, pencemaran air, hingga tanah menjadi penyebab ekosistem menjadi terganggu bahkan mati. Sampah plastik 
seperti botol terbuat dari bahan polyethylene terephthalate atau PET disinyalir mengandung zat karsinogen salah satu penyebab penyakit kanker. Dari sekeluruhan aspek sampah berupa botol plastik ataupun styrofoam sebagian besar dapat didaur ulang jika dimanfaatkan dengan baik. Banyak cara penanganan limbah anaorganik seperti dengan penimbunan, dibakar, daur ulang, pengurangan pengguanaan plastik, dan lainnya.

Salah satu tekhnik pemanfaatan ulang sampah-sampah anorganik tersebut dapat dilakukan dengan menjadikan barang bekas tersebut menjadi wadah untuk bertanam, selain praktis, mudah diperoleh, ekonomis, dan ramah lingkungan. Untuk itu tekhnik bercocok tanam yang dimaksud yaitu dengan menerapkan system aquaponik diperkarangan rumah (Fatmah Hiola, dkk, 2020:39). Pemanfaatan Styrofoam bekas sebagai wadah media bercocok tanam dinilai dapat diterapkan dalam kehidupan sehari-hari (Hartono, dkk, 2020:638).

Dalam merealisasikan tujuan dari penelitian ini, maka diadakan kegiatan sosialisasi oleh mahasiswa KKN Kelompok 106 Universitas Islam Negeri Sumatera Utara (Uinsu) kepada kelompok masyarakat Desa Pasiran, Kec. Sei Dadap, Kab. Asahan. Sosialisasi ini merupakan bentuk dari suatu pengabdian mahasiswa dari bentuk akademika terhadap masyarakat dengan menerapkan system bercocok tanam yang lebih efektif dan efesien penerapannya yaitu dengan melakukan system aquaponik sederhana.

\section{Metode}

Penelitian dilakukan di Desa Pasiran, Kecamatan Sei Dadap, Kabupaten Asahan. Kegiatan penelitian ini dilaksanakan pada tanggal 29 Juli-04 Agustus 2021. Target penelitian adalah masyarakat setempat di Desa Pasiran.

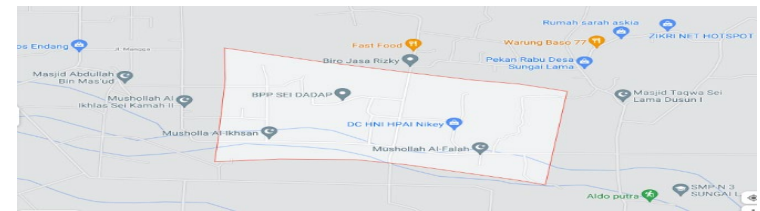

Gambar 1. Lokasi Penelitian di Desa Pasiran, Kec. Sei Dadap. Kab. Asahan

Metode pada penelitian ini menggunakan metode kualitatif dengan riset fokus group discussion (FGD) penyampaian secara langsung pada masyarakat, pegawai, dan komunitas Ibu PKK (Pembinaan Kesejahteraan Keluarga) di Desa Pasiran sebagai stakeholders penerapan sistem aquaponik dilingkungan rumah. Penelitian ini dilakukan dengan dua tahapan, yaitu penyemaian pada bibit kangkung dan pembuatan media tanam aquaponik dari limbah bekas anorganik.

Sosialisasi pada masyarakat dilakukan dengan mengadakan pertemukan di Balai Desa Pasiran dengan memberikan penyuluhan terkait konsep dan kontek sistem aquaponik selama 10 menit penyampaian teori, 5 menit pemutaran video pembuatan sistem aquaponik sederhana yang sudah dilakukan oleh mahasiswa KKN Uinsu, dan 5 menit kegiatan tanya jawab.

\section{Prosedur Kerja}

Persiapan Bahan:

1. Bibit kangkung

2. Air

3. Tanah

Persiapan Alat:

1. Styrofoam

2. Gelas plastik

3. Pisau/gunting

4. Kain lap

5. Botol semprot

Tahapan Pembuatan Aquaponik Sederhana

Tahapan Awal:

1. Menyemaikan bibit kangkung selama satu hari dengan cara merendamnya

2. Setelah itu saring menggunakan kain lap

3. Masukan benih kangkung 5 biji ke dalam gelas plastik yang sudah dilubangi secara acak dan telah berisikan tanah

4. Lakukan penyiraman secara rutin pagi dan sore hari menggunakan botol semprot hingga kangkung 
Jurnal Edumaspul, 5 (2), Year 2021 - 59

(Nurul Jannah, Melinia Maduratna, Ade Widya Claudia)

tumbuh berkecambah menjadi tinggi.

\section{Tahapan Akhir:}

1. Melubangi pada bagian atas styrofoam sebanyak 3-4 lingkaran dengan membuat diameter sebesar gelas plastik yang akan digunakan

2. Tuangkan air hingga setengah dari bagian styrofoam lalu tutup

3. Kemudian, masukkan tanaman kangkung yang sudah tumbuh didalam gelas plastik.

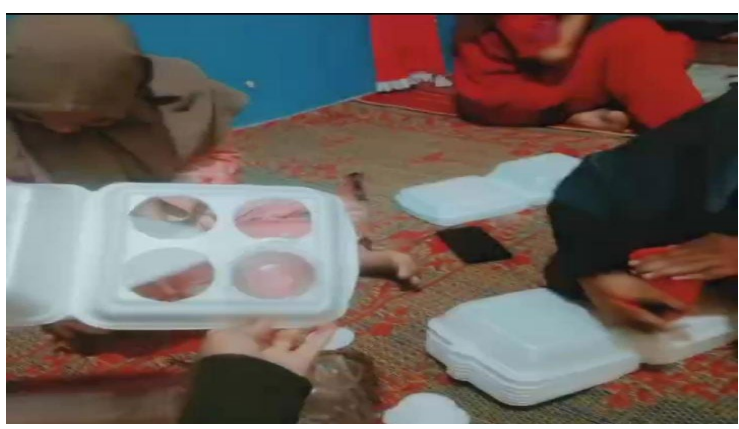

(1)

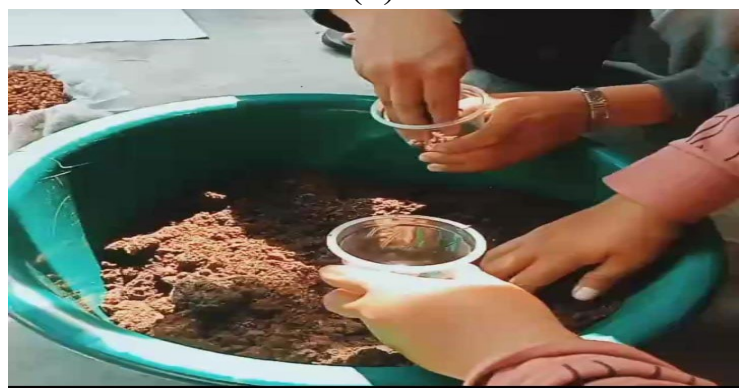

(2)

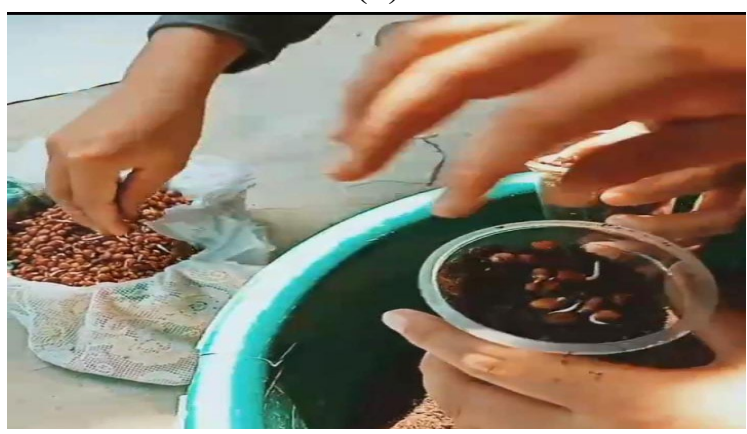

(3)

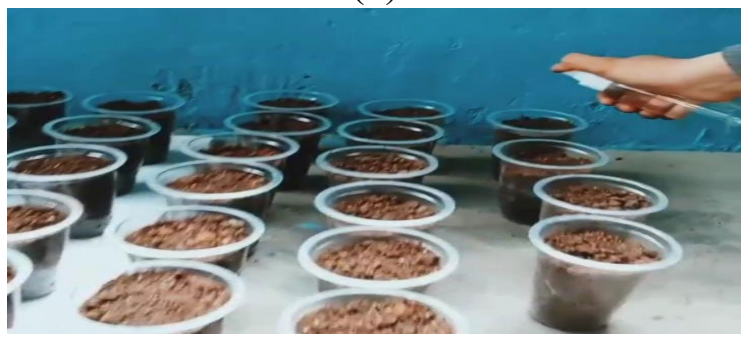

(4)

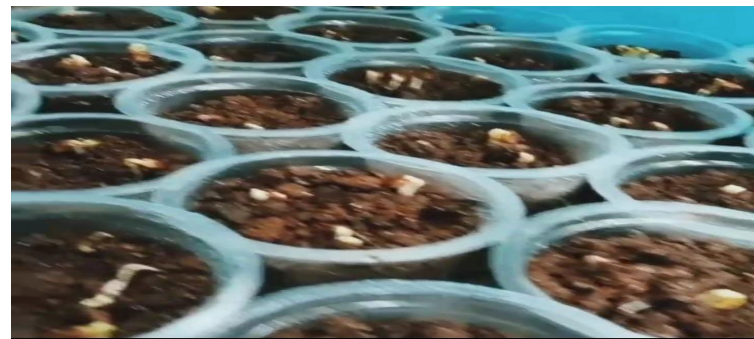

(5)

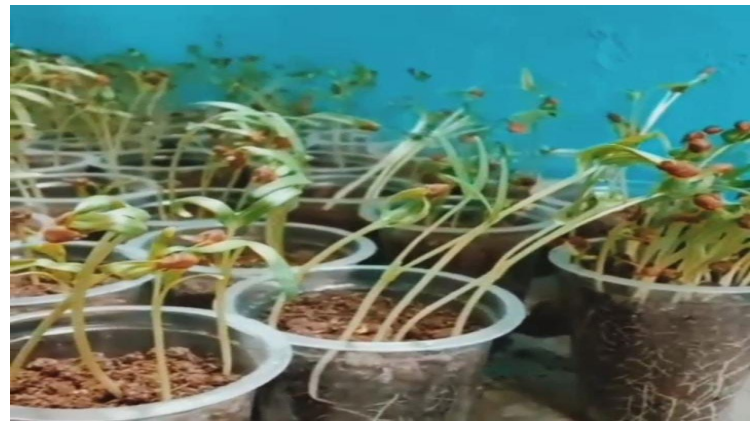

(6)

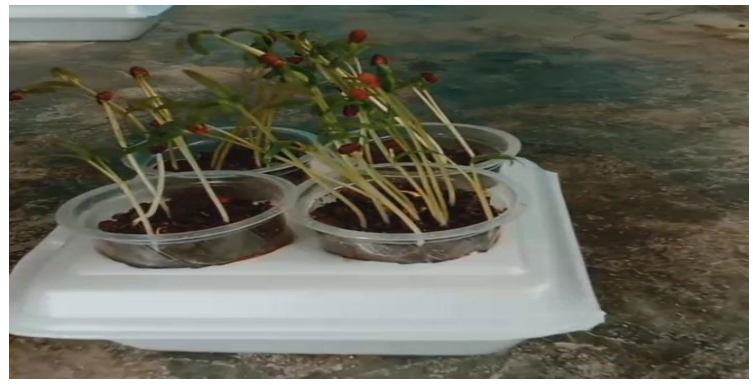

(7)

Gambar 2. Rancangan pembuatan aquponik sederhana. 1) limbah anorganik styrofoam sebagai wadah tanaman; 2) tanah bakaran yang subur; 3) bibit yang sudah disemai; 4) penyiraman; 5) perkecambahan awal; 6) kangkung yang sudah mulai tumbuh; 7) media aquaponik sudah siap

\section{Hasil dan Pembahasan}

Beberapa Negara di Dunia pada saat ini sedang menghadapi dampak virus covid19 (Corona Virus Disease 2019), tak terkecuali Indonesia. Semenjak adanya virus covid-19 ini menyebabkan mobilitas dan sector parawisata serta perekonomian di Indonesia mengalami penurunan yang signifikan. Hal ini juga berdampak langsung oleh kehidupan masyarakan di Desa Pasiran, Kec. Sei Dadap, Kab. Asahan.

Aquaponik adalah perpaduan antara budidaya ikan dan budidaya tanaman yang dilakukan secara hidroponik dalam satu 
Jurnal Edumaspul, 5 (2), Year 2021 - 60

(Nurul Jannah, Melinia Maduratna, Ade Widya Claudia)

wadah (Nugroho et al, 2012). Untuk itu mahasiswa KKN Kelompok 106 Universitas Islam Negeri Sumatera Utara (Uinsu) melakukan sosialisasi secara langsung kepada masyarakat di Desa Pasiran, Kec. Sei Dadap, Kab. Asahan terkait penerapan budidaya tanaman kangkung menggunakan sistem Aquaponik Sederhana. Dimana masyarakat dapat mengkonsumsi sayuran organik bebas dari zat kimia serta memberikan peluang usaha ditengah pandemic virus covid-19 tanpa memikirkan lahan yang terbatas dan biaya yang besar.

Sosialisasi dilakukan oleh mahasiswa KKN Uinsu dengan memberikan pengenalan tentang sistem aquaponik baik dari segi cara penggunaan, pemanfaatan, serta penerapannya dilingkungan sekitar rumah. Sosialisasi budidaya kangkung dengan media tanam sistem aquaponik ditampilkan pada slideshow dilayar yang sudah dibuat sebelumnya oleh mahasiswa KKN kelompok 106 Uinsu, pemutaran video dilakukan untuk memberi gambaran kepada masyarakat Desa Pasiran bagaimana prosedur pembuatan sistem aquaponik sederhana.

Sosialisasi ini bertujuan untuk dijadikan sebagai salah satu alternatif pengetahuan yang baru bagi para petani dan ibu-ibu rumah tangga di Desa Pasiran untuk dapat mengubah pola hidup yang lebih sehat dan baik dengan mengkonsumsi sayuran organik dan menjadikan satu peluang usaha dalam mengisi waktu yang cukup ditengah pandemic covid-19 saat ini.

Seperti yang telah dipaparkan oleh Dian Puspitasari, dkk (2020) top point keuntungan dari sistem aquaponik adalah penggunaan dari sumber daya paling efisien seperti peningkatan sektor ternak ikan yang mudah dan input fosfor, air, energi dan nutrisi yang dapat bermanfaat bagi tumbuhan dan bertahan dalam jangka panjang.

Air digunakan sebagai komponen paling penting bagi pertumbuhan pada tanaman kangkung. Dengan sistem aquaponik sederhana ini tumbuhan kangkung dapat berkembang lebih cepat dari biasanya.

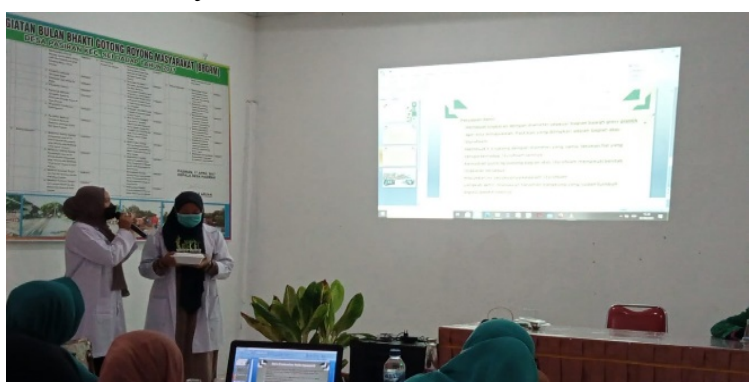

Gambar 3. Pengenalan sistem aquaponik

Aquaponik bisa dianggap sebagai integrasi dari dua teknologi yang berbeda dimana aquaponik ini merupakan sistem pertania modern yang memanfaatkan air yang kaya akan nutrisi dibandingkan tanah untuk proses pemeliharaan tanaman. Menurut Ali AlShrouf (2017) dikatakan bahwa keuntungan dari budidaya modern aquaponik ini adalah konservasi air dan tidak adanya penggunaan bahan kimia yang berbahaya bagi kesehatan tubuh (Dian Puspitasari, dkk, 2020).

Selain itu tehnik penggunaan ulang sampah-sampah anorganik dapat dilakukan dengan menjadikan barang bekas Styrofoam dan gelas plastik sebagai wadah untuk proses menanam. Penggunaan barang bekas ini juga dapat meminimalisir pengeluaran biaya, mudah diperoleh, tahan lama, dan mengurangi pencemaran terhadap lingkungan.
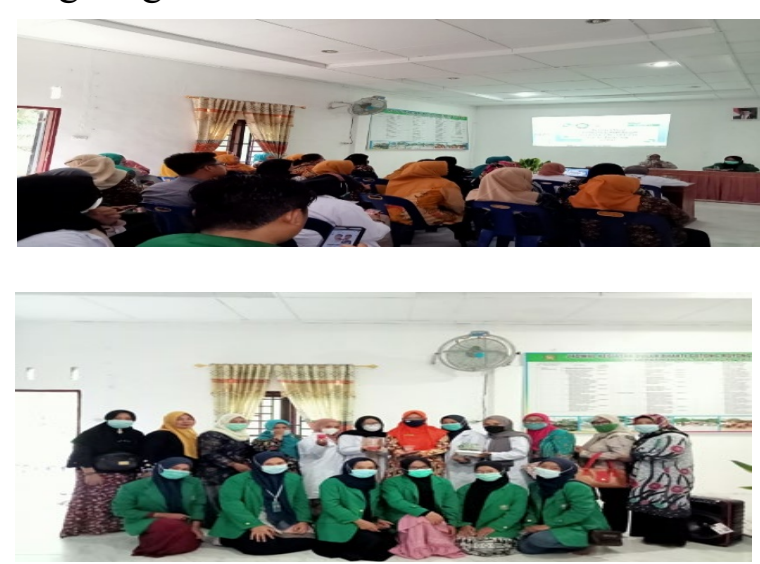

Gambar 4. Evaluasi akhir dan Foto bersama Adapun manfaat yang diperoleh dari sosialisai sistem aquaponik sederhana di Desa Pasiran yaitu:

1. Menghasilkan produk sayuran organik 
Jurnal Edumaspul, 5 (2), Year 2021 - 61

(Nurul Jannah, Melinia Maduratna, Ade Widya Claudia)

2. Pemanfaatan lahan sempit bercocok tanaman

3. Menghijaukan perkarangan rumah

4. Bebas dari tumpukan sampah dengan menguangi limbah botol bekas dan styrofoam

5. Mendapatkan wawasan bertani yang baru

6. Menjadi nilai produksi usaha dengan memanfaatkan hasil yang lebih baik

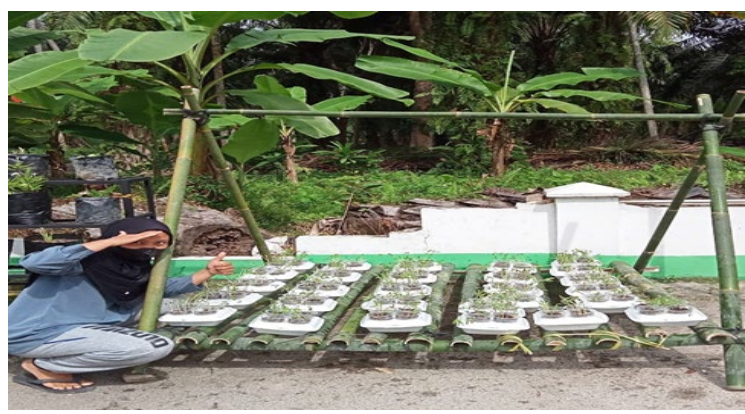

Gambar 5. Peletakan bibit kangkung pada rak berumur lima hari yang sudah muncul akar

Kegiatan monitoring pertumbuhan sayur kangkung dilakukan seminggu sekali untuk melihat air yang sudah berkurang pada wadah styrofoam. Untuk posisi tanaman diletakkan pada tempat yang mengenai paparan sinar matahari secara langsung agar mempercepat proses fotosintesis dan pemanenan.

\section{Simpulan}

Sistem Aquaponik adalah gabungan dari budidaya ikan dan budidaya tanaman. Dengan sistem aquaponik sederhana masyarakat dapat mengkonsumsi sayuran organik bebas akan bahan kimia serta peluang usaha ditengah pandemic virus covid-19 di Desa Pasiran, Kec. Sei Dadap, Kab. Asahan. Dimana penggunaan ulang sampah-sampah anorganik dapat dilakukan dengan menjadikan barang bekas Styrofoam dan gelas plastik sebagai wadah untuk proses menanam.

\section{Daftar Pustaka}

[1] Agustian, Dita, dkk. 2017. Efektifitas Pembelajaran Berbasis Masalah Dalam Meningkatkan Sikap Kepedulian Lingkungan Siswa (Studi Kasus Pada
Permasalahan Lingkungan Global). Jurnal BIOSFER, J.Bio \& Pend. Bio. Vol 2 (1): 43-48.

[2] Hartono, dkk. 2020. Pemanfaatan Styrofoam Bekas Sebagai Wadah Tanam Dalam Teknik Budidaya Tanaman Secara Hidroponik. Seminar Nasional Hasil Pengandian Masyarakat.

[3] Hiola, Fatmah, dkk. 2020. Pemanfaatan Barang Bekas Dalam Bercocok Tanam Secara Hidroponik Bagi Masyarakat Pesisir. Jurnal Dedikasi. Vol 22 (1): 3942.

[4] Mukharomah, Ervina, dkk. 2021. Pengaruh Penerapan Model Pembelajaran Problem Based Learning (PBL) Terhadap Kemampuan Kognitif Mahasiswa Pada Mata Kuliah Pengetahuan Lingkungan. Jurnal BIOSFER, J.Bio \& Pend. Bio. Vol 6 (1): 32-36.

[5] Pratopo, Lukito Hasta dan Ahmad Thoriq. 2021. Produksi Tanaman Kangkung dan Ikan Lele Dengan Sistem Aquaponik. Jurnal Ilmiah Pertanian. Vol 9 (1): 68-76.

[6] Puspitasari, Dian, dkk. 2020. Pemanfaatan Lahan Perkaranan Dengan Sistem Aquaponik Dalam Menunjang Perekonomian Di Desa Sungai Lama, Kabupaten Asahan, Sumatera Utara. Jurnal Anadara Pengabdian Kepada Masyarakat. Vol 2 (1): 67-71.

[7] Rahmdhani, Laela Endah, dkk. 2020. Kualitas Mutu Sayuran KASEPAK (Kangkung, Selada, Dan Pakcoy) Dengan Sistem Budidaya Akuaponik Dan Hidroponik. Jurnal Agroteknologi. Vol 14 (1): 33-43.

[8] Suliartini, Ni Wayan Sri, dkk. 2021. Optimalisasi Pemanfaatan Lahan Perkarangan Sebagai Penyangga Ketahanan Pangan Keluarga. Jurnal Pengabdian Magister Pendidikan IPA. Vol 4 (2): 106-113.

[9] Widyawati, Dewi Kania, dkk. 2021. Pemberdayaan Kemandirian Kelompok 
Jurnal Edumaspul, 5 (2), Year 2021 - 62

(Nurul Jannah, Melinia Maduratna, Ade Widya Claudia)

Pengajian BKP Dengan Pelatihan Aquaponik Dalam Pemanfaatan Lahan Sempit Untuk Ketahanan Pangan. Jurnal Pengabdian Nasional. Vol 2 (1): 1-10.

\section{Profil Penulis}

Penulis pertama yaitu Nurul Jannah. Penulis lahir di Pulau Rakyat Tua, 04 Juli 2000. Menetap di Sei Piring, Kabupaten Asahan. Pendidikan Strata (S1) ditempuh penulis di Universitas Islam Negeri Sumatera Utara (UINSU) tahun $2018 \mathrm{di}$ Fakultas Ilmu Tarbiyah dan Keguruan program studi Pendidikan Biologi. Saat ini penulis tercatat sebagai mahasiswa di Universitas Islam Negeri Sumatera Utara.

Penulis kedua yaitu Melinia Maduratna. Penulis lahir di Sentral, 08 Desember 1999. Menetap di Tinggi Raja, Kabupaten Asahan. Pendidikan Strata (S1) ditempuh penulis di Universitas Islam Negeri Sumatera Utara (UINSU) tahun 2018 di Fakultas Ilmu Tarbiyah dan Keguruan program studi Pendidikan Biologi. Saat ini penulis tercatat sebagai mahasiswa di Universitas Islam Negeri Sumatera Utara.

Penulis ketiga yaitu Ade Widya Claudia. Penulis lahir di Tanjung Balai, 30 Oktober 2000. Menetap di Tanjung Balai, Kabupaten Asahan. Pendidikan Strata (S1) ditempuh penulis di Universitas Islam Negeri Sumatera Utara (UINSU) tahun 2018 di Fakultas Ilmu Tarbiyah dan Keguruan program studi Pendidikan Biologi. Saat ini penulis tercatat sebagai mahasiswa di Universitas Islam Negeri Sumatera Utara. 